\title{
SOURCES OF MERCURY IN THE ARCTIC
}

\author{
J.M. PACYNA ${ }^{1}$ AND G.J. KEELER ${ }^{2}$ \\ ${ }^{1}$ Norwegian Institute for Air Research (NILU), P.OBox 100, 2007 Kjeller, Norway \\ ${ }^{2}$ The University of Michigan, School of Public Health, 109 Observatory, Ann Arbor, MI 48109-2029, USA
}

\begin{abstract}
Global and regional emission inventories of mercury are reviewed with special emphasis on the source regions with potential impact on the Arctic environment. These sources are located mostly in Eurasia and North America and emit almost $1300 \mathrm{t}$ of $\mathrm{Hg}$ to the air annually. Combustion of fossil fuels to produce electricity and heat is the major source of $\mathrm{Hg}$. Major portion of the element emissions from this source is in a gaseous phase. A small portion of $\mathrm{Hg}$ emissions in Eurasia and North America is deposited in the Arctic region, perhaps 60 to $80 \mathrm{t}$ annually. Additional amounts of $\mathrm{Hg}$ in the Arctic air originate from natural sources, although it is very difficult to quantify them. A small decrease of anthropogenic $\mathrm{Hg}$ emissions is observed in Europe at present. These emissions are expected to increase again in the near future.
\end{abstract}

\section{Introduction}

Mercury has been measured in environmental samples collected in the Arctic and sub-Arctic region (e.g. SFT, 1994). Although the most of these measurements were carried out in the aquatic and terrestrial environments, atmospheric $\mathrm{Hg}$ deposition was also studied, particularly in northern Scandinavia (e.g. Iverfeld, 1991). A summary of recently reported concentrations, including those in the northern regions and deposition rates has been prepared by Munthe (1993). The atmospheric pathway is clearly contributing to the contamination of other compartments of the environment by $\mathrm{Hg}$, also in the Arctic region. Both, direct and indirect estimates of total deposition of the element proved this hypothesis. Direct estimates of the total deposition can be carried out on the basis of information on emissions which are then used in various dispersion models. The indirect estimates are based on the element concentrations in peat bogs, lake sediments, and mosses.

During the last few, years long- range transport of $\mathrm{Hg}$ within air masses has been studied in Europe and North America (e.g. Petersen, 1993). It was concluded that $\mathrm{Hg}$ deposition predicted by a Lagrangian trajectory model applied in Europe agrees with observations from the Scandinavian deposition network (Iverfeld, 1991) within a factor of two (Petersen et al., 
1994). Even better agreement can be obtained through the improvement of mercury emission data, particularly with respect to the chemical speciation of the element.

Recent $\mathrm{Hg}$ measurements in peat bogs in Norway show a decrease of the element concentrations with depths corresponding to a time period of about 100 to 200 years (Steinnes and Andersson, 1991), thus, clearly indicating the effect of anthropogenic activities. The effect of long-range transport of $\mathrm{Hg}$ was also investigated using the element concentrations in moss as indicator of the atmospheric deposition over Scandinavia (Steinnes and Andersson, 1991). A south to north decreasing concentration gradient was observed except for the regions far north. The authors speculated that the enhanced dry deposition of $\mathrm{Hg}$ in the north can be related to a cold climate.

It can be concluded from the above mentioned and other studies that $\mathrm{Hg}$ can be transported within air masses to the Arctic and sub-Arctic regions and at least partially deposited there. How much of $\mathrm{Hg}$ can be brought to and deposited within these regions depends on many parameters. One of the most important parameters is the amount of emissions of the element, particularly in the regions with a potential impact on the Arctic environment. The purpose of this work is to assess emission fluxes of $\mathrm{Hg}$ with focus on emission regions having possible impact on the contamination of the Arctic and sub-Arctic air. Location of these sources is also described.

\section{Global Fluxes of Mercury}

Although quite extensive information exists on environmental and health effects of mercury and its behavior in the environment, much less information is available on the fluxes of the element to the air, water, and soils. The first quantitative worldwide estimate of the annual industrial inputs of 16 elements to the environment, including $\mathrm{Hg}$ has been prepared by Nriagu and Pacyna (1988). Summary of these estimates for the mïd 1980's is presented in Table I. It can be concluded that the $\mathrm{Hg}$ emission to the air is comparable with direct inputs of the element to the aquatic environment and are almost a half of the direct releases to the terrestrial environment. No re-emission of $\mathrm{Hg}$ from the aquatic and terrestrial surfaces to the air was considered in these estimates. 
Combustion of fossil fuels to produce electricity and heat is the major source of atmospheric emissions of $\mathrm{Hg}$ on a global scale. Major portion of $\mathrm{Hg}$ emissions from combustion of fuels is in a gaseous phase. In the combustion zone $\mathrm{Hg}$ present in coal or other fossil fuels evaporates in elemental form and then most likely a portion of it is oxidized while in the flue gases. The oxidized forms of $\mathrm{Hg}$ can be retained in modern flue gas cleaning systems. Mercury retained in fly ash (as well as in bottom ash) is then disposed on land or finds its way in a form of direct releases to the aquatic environment. It is very difficult to quantify these processes.

\section{TABLE I}

Global inputs of anthropogenic $\mathrm{Hg}$ to the environment (in $10^{3} \mathrm{t} / \mathrm{y}$ ) based on estimates by Nriagu and Pacyna (1988)

\begin{tabular}{lll}
\hline Environmental compartment & Source category & Emission \\
\hline AIR & Combustion of fuels & $0.7-3.8$ \\
& Industrial manufacturing & $0.1-0.2$ \\
& Refuse incineration & $0.2-2.1$ \\
& Sub total & $1.0-6.1$ \\
WATER & Direct releases & $0.1-6.7$ \\
& Dumping of sewage sludge & $0.1-0.3$ \\
& Atmospheric deposition & $0.4-1.8$ \\
SOIL & Sub total & $0.6-8.8$ \\
& Direct releases & $1.0-10.7$ \\
& Atmospheric deposition & $0.6-4.3$ \\
& Sub-total & $1.6-15.0$ \\
\hline
\end{tabular}

Nriagu and Pacyna (1988) estimated that $\mathrm{Hg}$ in coal fly ash and bottom ash contribute up to $40 \%$ of the direct releases of the element to the terrestrial environment. As much as $40 \%$ of $\mathrm{Hg}$ entering the utility boilers in the United Kingdom is retained in flue gas control equipment and appears as liquid and solid wastes (in Pacyna, 1994). However, one should observe that 
the flue gas control equipment, particularly the one for removal of gaseous pollutants is available mostly in the developed countries.

Refuse incineration seems to be the second largest source of $\mathrm{Hg}$ emissions to the atmosphere. Emission generation process for $\mathrm{Hg}$ during the incineration of wastes is similar to that during combustion of fossil fuels. However, more $\mathrm{Hg}$ in the oxidized form is expected from incinerators due to the higher content of chlorine in the wastes compared to fossil fuels.

While in the atmosphere, $\mathrm{Hg}$ undergoes various physical and chemical transformations (e.g. a review by Munthe, 1993) and finally is removed from the air by wet and dry deposition. Nriagu and Pacyna (1988) estimated that deposition on terrestrial surfaces is more than twice the deposition on aquatic surfaces (Table I).

Natural $\mathrm{Hg}$ emissions result from various processes including the off-gassing of $\mathrm{Hg}$ ladden rock, and volatilization of $\mathrm{Hg}$ from soils and vegetation, as well as from various water bodies. Mercury enters the atmosphere as a result of forest fires, volcanic activity, and other biomass burning. Elevated ambient temperatures tend to increase the rate of $\mathrm{Hg}$ loss from soils. Very few direct measurements of the flux of $\mathrm{Hg}$, by species, have been made to date under a wide enough set of meteorological conditions to allow for extrapolation of the old data to the present day. On the basis of recent information on re-emission rate from water and soil it can be suggested that the natural emissions of $\mathrm{Hg}$ are of the same order as the emissions from anthropogenic sources.

It should be noted that emissions from natural sources are difficult to distinguish from secondary emissions and diffusive re-emissions from anthropogenic sources. These include reemissions of previously deposited $\mathrm{Hg}$, emissions resulting from discharge into water bodies and from contaminated soils. Hence, it is more appropriate to differentiate between preindustrial and post-industrial diffuse sources (e.g. Lindqvist, 1991).

\section{Sources of Atmospheric Mercury in the Arctic and sub-Arctic}

Obviously, only a part of worldwide emission sources is responsible for the contamination of the Arctic environment. However, no quantitative assessment is available to conclude in details on the origin of $\mathrm{Hg}$ in the Arctic air. Therefore, information on the origin of other trace 
elements and sulfur has been utilized in this paper to suggest the possible sources and source regions for mercury in the Arctic air. Of particular interest in this case are trace elements emitted from the combustion of fossil fuels and the incineration of wastes. They include antimony, arsenic, cadmium, zinc, selenium, nickel, and vanadium. The differences in the fate and the environmental behavior of $\mathrm{Hg}$ and the above mentioned trace elements were taken into account.

A quantitative assessment of the contribution of carbonaceous fuel combustion emissions to the Norwegian Arctic haze layers has been made using the receptor modeling approach (Maenhaut et al., 1989), and two different dispersion modeling approaches (Pacyna et al.,1985; Akeredolu et al., 1994). The assessment showed that up to 50\% of various air pollutants, measured in the Arctic during winter and summer, were from fuel burning. Sulfur could not be quantitatively assessed owing to uncertainties in the magnitude of natural marine biogenic emissions and their fluxes to the Arctic. There is an indication, however, that over $50 \%$ of the non-sea salt sulfate present in the Norwegian Arctic is from fuel burning (Maenhaut et al., 1989), and a similarly high percentage has been estimated for Barrow, Alaska, as well ( $\mathrm{Li}$ and Winchester, 1989). Taking into account the above discussion on the presence of combustion-related air pollutants in the Arctic one can conclude that also $\mathrm{Hg}$ can be transported to this region.

An important question is where are the source regions which may contribute to the contamination of the Arctic and sub-Arctic air by $\mathrm{Hg}$. No such source-receptor relationship studies have been carried out for the element. However, these relationships were studied for other trace elements emitted during the combustion of fossil fuels, as well as for sulfur (e.g. Maenhaut et al., 1989). The results of these studies can be summarized as follows. Emissions from sources in Eurasia contribute more than half of the air pollution measured in the Arctic. The major source regions include the Urals, the Kola Peninsula, the Norilsk area, and the industrial regions in central Europe. Emissions from the Urals and the Norilsk area may be more important for the contamination of air over Alaska and the Canadian Arctic, whereas sources in the Kola Peninsula contribute more to the Norwegian Arctic. The contributions of the European and North American emissions to Arctic air pollution seem to be lower than the contribution from the Russian sources. The European and North American emission are, 
however, major contributors to the contamination of the sub-Arctic regions, such as northern Scandinavia (the European emissions) and northern part of Canada (the North American emissions).

Obviously, there are also local sources within the Arctic and sub-Arctic region. Combustion of fossil fuels to produce electricity and heat is one of the major source categories present in the region, particularly for atmospheric $\mathrm{Hg}$. However, the impact of these sources on the contamination of the Arctic air is on local scale only (e.g. Ottar et al., 1986).

\section{Emissions of Mercury in Europe, North America, and Northern Asia}

A summary of atmospheric emissions of $\mathrm{Hg}$ from anthropogenic sources in Europe, including the European part of Russia, the United States, and Canada is presented in Table II. The most recent European emission inventory for the element uses the 1987 statistical data (Axenfeld et $a l ., 1991)$. The inventory was prepared on the basis of emission factors and the results of these estimates are shown in Table $\Pi$. These regional estimates were then compared with national emission data available from some countries. Both national and regional emission inventories indicate that the combustion of fuels, particularly coal, emits more than half of the atmospheric $\mathrm{Hg}$ in Europe (Pacyna, 1994). In some countries where combustion of coal is the predominant method to produce heat and electricity, the contribution of $\mathrm{Hg}$ emission from fuel combustion to the total national emission of the element is even bigger. A recent emission report from Poland concludes that fuel combustion generates more than $75 \%$ of the atmospheric $\mathrm{Hg}$ in the country (Hlawiczka, 1994).

Emissions from waste incineration in Table II are clearly underestimated. They represent emission data collected from 8 European countries only.

A national emission inventory of $\mathrm{Hg}$ and $\mathrm{Hg}$ compounds in 1990 has recently been prepared in the United States (US EPA, 1993). Emissions from combustion of fossil fuels contribute almost half of the US total emissions of $\mathrm{Hg}$, followed by emissions from incineration of wastes. The estimates made in Canada are quite old and new data for 1993 levels are expected by the end of 1994 (UN ECE, 1994). 


\section{TABLE I}

Atmospheric emissions of $\mathrm{Hg}$ from anthropogenic sources in Europe, the United States and Canada (in $\mathrm{t} / \mathrm{y}$ )

\begin{tabular}{lccc}
\hline Source category & $\begin{array}{l}\text { Europe, 1987 } \\
\text { (Axenfeld } \text { et al., 1991) }\end{array}$ & $\begin{array}{l}\text { The United States, 1990 } \\
\text { (US EPA, 1993) }\end{array}$ & $\begin{array}{l}\text { Canada, 1982 } \\
\text { (Jacques, 1987) }\end{array}$ \\
\hline $\begin{array}{l}\text { 1. Fossil fuel } \\
\text { combustion }\end{array}$ & 405 & 141 & 8 \\
$\begin{array}{l}\text { 2. Industrial } \\
\text { processes }\end{array}$ & 275 & 32 & 16 \\
$\begin{array}{l}\text { 3. Waste } \\
\text { incineration }\end{array}$ & 35 & 118 & 2 \\
$\begin{array}{l}\text { 4. Other sources } \\
\text { TOTAL }\end{array}$ & 11 & 19 & 5 \\
\hline
\end{tabular}

Information on spatial distribution of $\mathrm{Hg}$ emissions is available for Europe and North America. European emissions are distributed within the UN ECE European Monitoring and Evaluation Programme (EMEP) grid system of $150 \mathrm{~km}$ by $150 \mathrm{~km}$. This distribution is presented in Figure 1. Major emission sources are located in central and eastern Europe. Episodes of pollution transport from these regions to the Norwegian Arctic have been documented (e.g. Ottar et al., 1986). In comparison, emissions in Scandinavia are low and the $\mathrm{Hg}$ concentrations measured in the Scandinavian environment are to a great extent due to the long-range transport from other parts of Europe. High emissions of $\mathrm{Hg}$ in the United Kingdom should also be noted.

Information on the location of major point sources of $\mathrm{Hg}$ emissions is available for the United States. In addition, the state-by state data are also estimated (US EPA, 1993). The largest emissions are estimated for the states around the Great Lakes, mostly due to coal combustion in the region. Atmospheric transport of pollution from this region northwards, with additional inputs from sources in Ontario has been a subject of preliminary studies (Clark, 1992). Combustion of fossil fuels in Alaska contributes about $1 \%$ of the $\mathrm{Hg}$ emissions from this source category in the country. A dozen of municipal waste incinerators and three sewage sludge incinerators in Alaska do not generate any significant emissions of atmospheric $\mathrm{Hg}$. 


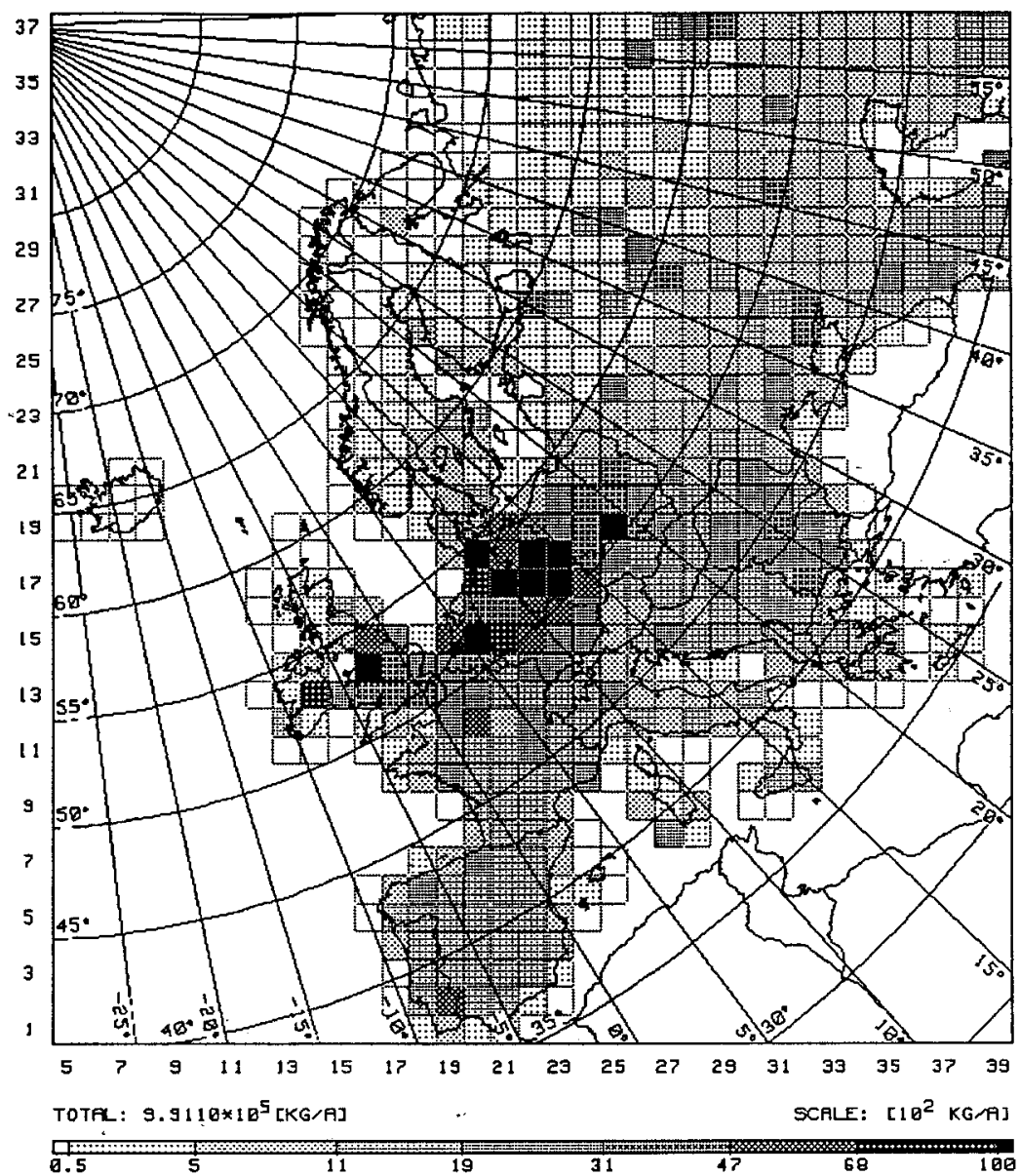

Fig. 1. Spatial distribution of total (anthropogenic and natural) emissions of mercury in Europe in 1987 within the EMEP grid system of $150 \mathrm{~km}$ by $150 \mathrm{~km}$.

The Canadian emission data are available for all provinces, separately (Jacques, 1987). The largest emissions, about $10 \mathrm{t}$ in 1982, were estimated for Manitoba, followed by North West Territories, Quebec, and Ontario. Huge emissions of about $3500 \mathrm{t} / \mathrm{yr}$ were calculated for natural sources in the country (in Voldner and Smith, 1989). These natural emissions are by far overestimated due to the overestimation of emission factors used in these calculations. 
Less information is available on emissions of $\mathrm{Hg}$ in Asia, particularly in the northern part of the continent. Major emission source regions in the former Soviet Union and the emission quantities for several heavy metals were reviewed by Pacyna (1984). These data were used to assess the $\mathrm{Hg}$ emissions in this region. The results are presented in Table III. Again, the combustion of fossil fuels is the major source of atmospheric $\mathrm{Hg}$ emissions. The emissions from sources in the Ural dominate the emissions from other sources mentioned in Table III. The sources in the Ural include the production of non-ferrous and ferrous metals, chemical industry, and building material industry in addition to the combustion of fossil fuels (e.g. Pacyna, 1984). There are also other large source regions in the Asian part of the former Soviet Union, generating $\mathrm{Hg}$ and other trace element emissions to the air. They include the Kuznetsk area, the Fergana area, Caucasus, and the Baikal area. The location of these source regions in the southern part of the former Soviet Union raises a question whether sources a few thousand kilometers away can contribute to the $\mathrm{Hg}$ levels in the Arctic. Such very long range transport was suggested for some pesticides, e.g. lindane, used extensively in Asia and measured in the Arctic air (e.g. Pacyna and Oehme, 1988), and some crustal elements originating during dust storms in the Asian deserts and measured at elevated altitudes in the Arctic air (e.g. Pacyna and Ottar, 1989).

\section{TABLE III}

Mercury emissions from anthropogenic sources in the former Soviet Union at the beginning of the 1980 's (in $t / y$ )

\begin{tabular}{lccr}
\hline Region & $\begin{array}{c}\text { Combustion of } \\
\text { fossil fuels }\end{array}$ & Industrial sources & Total \\
\hline 1. The Kola Peninsula & 14 & 6 & 20 \\
2. The Pechora Basin & 6 & 2 & 8 \\
3. The Norilsk Area & 14 & 6 & 20 \\
4. The Urals & 110 & 44 & 154 \\
5. The Yakutsk Area & 22 & 2 & 24 \\
\hline
\end{tabular}

The total emissions of $\mathrm{Hg}$ in Eurasia and North America are about $1300 \mathrm{t} / \mathrm{y}$. No estimates were performed to assess what portion of these emissions enter the Arctic region and is 
deposited there. Such calculations were made for other trace elements. An estimated 11 to $14 \%$ of antimony, arsenic, cadmium, lead, zinc, and vanadium, predicted to be entering the Arctic by the model used by Akeredolu et al. (1994) are deposited there. As much as $12 \%$ of the anthropogenic sulfur reaching this region from mid-latitudes is deposited in the Arctic (Jickells et al., 1988). It was also estimated that up to $6 \%$ of the total emissions of arsenic, cadmium, lead, zinc, vanadium, and antimony in all of Eurasia is deposited in the Arctic (in UN ECE, 1994). About 6\% of sulfur emissions in Eurasia is also deposited in the Arctic (Barrie et $a l_{\mathrm{s}}, 1989$ ). If the same proportion is true for $\mathrm{Hg}$, up to $60 \mathrm{t}$ of the element emitted in Eurasia can be deposited from the air in the Arctic region annually. Additional quantities of the element would originate from anthropogenic and natural sources of $\mathrm{Hg}$ in North America.

\section{Trends of Mercury Emissions}

The decreasing trend of $\mathrm{Hg}$ levels in the atmospheric deposition in Scandinavia has been observed during the last few years (Munthe et al., 1994). This trend was related to possible decline of $\mathrm{Hg}$ emissions, particularly in Central and Eastern Europe. As much as 30\% decrease of these emissions can be expected. The decline of the economical growth in this part of Europe at the beginning of the 1990 's, related to the transition of the centrally planned economies in these countries to the market oriented ones was suggested as the major reason for the possible changes of $\mathrm{Hg}$ emissions. No doubt, the lower consumption of fuels in Eastern Europe during the recent years has caused the decrease of $\mathrm{Hg}$ emissions.

Reasons for likely decrease of $\mathrm{Hg}$ emissions to the air in Western Europe and North America are different and relate mostly to the installation of control equipment removing sulfur and nitrogen compounds from exhaust gases in various industries. This equipment removes also other gaseous pollutants, including $\mathrm{Hg}$.

An interesting question is whether the above mentioned-decline of $\mathrm{Hg}$ emissions into the air is a permanent process or whether an emission increase can be expected in the near future. Munthe et al. (1994) conclude that the industrial decline in Eastern Europe and consequently lower electricity and heat demands is only a temporary process. Therefore, emissions of $\mathrm{Hg}$ are expected to raise again in the near future. 


\section{References}

Akeredolu, F.A., Barrie, L.A., Olson, M.P., Oikawa, K.K., Pacyna, J.M., Keeler, G.J.: 1994, Atmos.Environ. 28, 1557-1572.

Axenfeld, F., Munch, J., Pacyna, J.M.: 1991, Europaische Test-Emissionsdatenbasis von QuecksilberKomponenten fur Modellrechnungen, Dornier Report, Friedrichshafen, Germany.

Barrie, L.A., Olson, M.P., Oikawa, K.K.: 1989, Atmos.Environ. 23, 2505-2512.

Clark, T.L.: 1992, Presented at the Joint Workshop on Mercury and Multimedia Risk Assessment, Durham, NC, 22 October, 1992.

Hlawiczka, S.: 1994, Report on Heavy Metals Emission in Poland for 1990, The Institute for Ecology of Industrial Areas, Katowice, Poland.

Iverfeld, Å.: 1991, Water, Air, Soil Pollut. 56, 251-265.

Jacques, A.P.: 1987, Summary of emissions of antimony, arsenic, cadmium, copper, lead, manganese, mercury, and nickel in Canada, Environmental Analysis Branch, Conservation and Protection, Environment Canada, Ottawa.

Jickells, T.D., Arimoto, R., Barrie, L.A., Church, T.M., Dehairs, F., Dulac, F., Mart, L., Sturges, W.T., Zoller, W.H.: 1988, in: The Long Range Atmospheric Transport of Natural and Contaminant Substances, NATO ASI Series 297, 177-196.

Li, S.-M. and Winchester, J.W.: 1989, Atmos.Environ. 23, 2401-2415.

Lindqvist, O.: 1991, Mercury in the Swedish Environment, Kluwer Academic Publ., Dordrecht, the Netherlands.

Maenhaut, W., Cornille, P., Pacyna, J.M., Vitols V.: 1989, Atmos.Environ. 23, 2551-2570.

Munthe, J.: 1993, in Proc. of the 1st Workshop on Emissions and Modelling of Atmospheric Transport of Persistent Organic Pollutants and Heavy Metals, Durham, NC, 6-7 May, 1993, 225-254.

Munthe, J., Iverfeld, Å., Brosset, C., Pacyna, J.M.: 1994, Effects of drastic economical changes in Eastern Europe on concentrations and wet deposition of atmospheric mercury in Sweden and Norway. In preparation for Nature.

Nriagu, J.O. and Pacyna, J.M.: 1988, Nature 333, 134-139.

Ottar, B., Gotaas, Y., Hov, Ø., Iversen, T., Joranger, E., Oehme, M., Pacyna, J.M., Semb, A., Thomas, W., Vitols, V.: 1986, Air Pollutants in the Arctic. NILU OR Rept, 30/86, the Norwegian Institute for Air Research, Lillestrøm, Norway.

Pacyna, J.M.: 1984, Emission sources in the Soviet Union. NILU TR Rept. 4/84, the Norwegian Institute for Air Research, Lillestrøm, Norway.

Pacyna, J.M.: 1994, in: EMEP Workshop on European Monitoring, Modelling and Assessment of Heavy Metals and Persistent Organic Pollutants, Beekbergen, the Netherlands, 3-6 May, 1994, 10-15.

Pacyna, J.M. and Oehme, M.: 1988, Atmos.Environ. 22, 243-257. 
Pacyna, J.M. and Ottar, B.: 1989, Atmos.Environ. 23, 809-815.

Pacyna, J.M., Ottar, B., Tomza, U., Maenhaut, W.: 1985, Atmos.Environ. 19, 857-865.

Petersen, G.: 1993, in Proc. of the 1st Workshop on Emissions and Modelling of Atmospheric Transport of Persistent Organic Pollutants and Heavy Metals, Durham, NC, 6-7 May, 1993, 261-279.

Petersen, G., Iverfeld, A., Munthe, J.: 1994, Atmos.Environ. (in press).

SFT: 1994, Arctic Monitoring and Assessment Programme (AMAP). The National Implementation Plan for the Participation of Norway, 1993. The State Pollution Control Authority, Oslo, Norway.

Steinnes, E. and Andersson, E.M.: 1991, Water, Air, Soil Pollut. 56, 391-404.

UN ECE: 1994, Heavy Metals. The UN Economic Commission for Europe, EB.AIR/WG.6/R.20, Geneva, Switzerland.

US EPA: 1993, National Emissions Inventory of Mercury and Mercury Compounds: Interim Final Report, The U.S. Environmental Protection Agency, EPA-453/R-93-048, Research Triangle Park, NC.

Voldner, E. and Smith, L.: 1989, Production, Usage and Atmospheric Emissions of 14 Priority Toxic Chemicals. Report of the Joint Water Quality Board/ Science Advisory Board/International Air Quality Advisory Board of the International Joint Commission. Presented at the Workshop on Great Lakes Atmospheric Deposition, 29-31 October, 1986. 